\title{
aniki
}

Revista Portuguesa da Imagem em Movimento

Portuguese Journal of the Moving Image

\section{A teatralidade como vetor do ensaio fílmico no documentário brasileiro contemporâneo ${ }^{1}$ Ismail Xavier $^{2}$}

Numa primeira formulação, o filme-ensaio foi visto como experiência derivada do documentário, tal como o fez Hans Richter em 1940 (cit. in Fihman 2004), mas podemos vê-lo também a partir do cinema experimental e de certas formas de invenção no campo ficcional tal como trabalhado no cinema moderno por cineastas como Resnais, Marker, Godard, Straub, Kluge. O melhor, no entanto, é pensá-lo como superação dessas fronteiras, como invenção que abriu um continente de indagações geradas no confronto entre o cinema e a filosofia. A ideia do filme como pensamento em ato, sob as formas "autônomas e insubstituíveis que os cineastas foram capazes de inventar" (Deleuze 1985, 8), teve certamente seu efeito no uso mais específico, mediado pela história da filosofia, da noção de ensaio referida aos filmes, um uso cada vez mais frequente na crítica, seja na lida com o novo cinema (e o novo vídeo), seja na análise de obras do cinema moderno, antes trabalhadas a partir de noções como cinema poético, desconstrutivo, experimental ou conceitual.

Falar em filme-ensaio envolve um posicionamento da crítica diante do seu objeto como um experimento, exame de uma questão sem o apelo às regras fechadas de um método, uma experiência intelectual mais aberta em que o pensamento se arrisca em terrenos onde a exatidão é impossível. E envolve também o senso de que tal exame responde à insistência de uma questão no espaço da cultura e a uma busca de apreensão do objeto em sua variabilidade, assumindo a legitimidade do transitório como foco de atenção. Há, na linhagem secular do ensaio, um impulso anti-sistêmico e a marca da subjetividade. Esta se faz presente de forma radical, mantendo uma relação tensa e produtiva com o teor de verdade almejado. Em suma, vale aí a "tensão entre construção e expressão" (como observa Theodor Adorno) que se pode reconhecer não apenas no ensaio filosófico, mas também nos agenciamentos de imagem-e-som que entrelaçam o conceitual, a abertura para o mundo e o exercício pleno da autoria ${ }^{3}$.

A dimensão reflexiva do ensaio, voltada para a própria representação, abre caminho para repensar as articulações entre ficção e

\footnotetext{
${ }^{1}$ Este texto retoma a conferência proferida pelo autor no III Encontro Anual da AIM, em Coimbra, em maio de 2013 (NdE).

${ }^{2}$ Universidade de São Paulo (Brasil).

${ }^{3}$ Ver Adorno (1962). Para uma discussão ampla sobre a questão do ensaio em geral e no âmbito da reflexão sobre o cinema, ver Liandrat-Guigues e Gagnebin (2004).
} 
documentário, ou entre cinema e "outras mídias" (não por acaso, Chris Marker é uma das balizas nesta discussão), uma vez que é uma referência conceitual que procura dar conta de um campo heterogêneo e em movimento. O risco é fazer dele uma noção polivalente em excesso a ponto de se descaracterizar, ultrapassando aquele limite a partir do qual tudo pode ser ensaio. Ficamos entre a definição restritiva como se estivéssemos falando de um gênero (regras) - o que não é o caso - e a indefinição geradora de um esvaziamento da noção.

Vale à pena explorar, a cada caso, o que seriam as marcas formais que nos permitem usar a noção, não apenas como forma econômica de resolver os problemas de fronteira, mas como presença afirmativa de um baliza para a análise. Para o que vou expor aqui, interessa acentuar a presença explícita de uma dimensão reflexiva que opera sobre questão pré-existente e nos obriga a reconhecer a imagem ou a cena como "forma que pensa" (Godard). Como "forma", ele supõe uma "arquitetura subjacente" (Starobinski 1985) ao movimento do pensar, arquitetura que se constitui de operações que devemos caracterizar, caso a caso.

Vou examinar aqui os procedimentos de Eduardo Coutinho em sua obra Jogo de cena (2007), filme cuja dimensão reflexiva vem aprofundar o debate sobre as relações entre cinema, performance e teatro, notadamente pela sua escolha de um espaço peculiar de filmagem e pelo estilo muito próprio de compor as cenas das entrevistas e sua sucessão, esta pontuada por mudanças de registro, interrupções nas quais o cineasta conversa sobre problemas da representação com três atrizes bem conhecidas.

Já nos anos 1960, a intensidade e a velocidade na circulação das imagens, sons, textos, iconografias, dentro e fora da esfera pública dos meios de comunicação, havia evidenciado a capacidade das novas mídias - como instância de polarização do mundo entre atores e espectadores (na arte, na publicidade, na política) - de redefinir a natureza do processo político, dentro de uma lógica que Guy Debord associou à noção de sociedade do espetáculo. Esta fórmula ganhou uso disseminado, embora nem sempre tivessem sido consideradas as suas implicações como teoria do atual regime da mercadoria. O que em geral prevaleceu foi uma intenção de reconhecer o aspecto sistemático, não incidental, da transformação de todas as esferas da experiência em imagem (ou cena), e o gesto de apontar as formas pelas quais isto dissolve os conteúdos de experiência em favor da espetacularização das relações sociais por ela mediadas.

Dentro desta dinâmica de relações pautada pelo fetiche da imagem como certificado de existência, ter uma câmera apontada para si tornou-se um "privilégio ontológico" gerador de uma ansiedade exibicionista. Impôs-se o "efeito câmera" como elemento que estrutura certas situações em que é inevitável a teatralidade, o pe- 
queno (ou grande) jogo social onde cada qual assume um papel - ou imagem - dentro de novas modalidades de convívio geradas pelo olhar dos aparelhos. Para Debord, a sociedade do espetáculo estava pautada pela oposição nítida entre os atores do jogo e seus espectadores passivos.

Entre os anos 1960 e o contexto atual, houve uma alteração que os estudiosos têm apontado: torna-se cada vez mais frequente uma estratégia de induzir à participação, criar o senso de que todos participam ou podem participar do espetáculo, na tele-ficção seriada, nos talk-shows ou nos reality-shows que compõem a síntese e metáfora de todo o processo tal como se manifesta na mídia.

O cinema tem tematizado esta lógica das novas relações de distintas formas, notadamente nos documentários, quando busca alternativas para lidar com o efeito-câmera e direcioná-lo para a construção de sujeitos-personagens (aqui, a ambiguidade se impõe) sem os constrangimentos trazidos pelo protocolo do espetáculo e seu voyeurismo, embora a cena montada pelo cineasta não dissolva esta teatralidade constitutiva implicada em seu dispositivo.

No momento do encontro para uma cena de entrevista, o documentário tem exibido uma variedade de caminhos para a composição da "personagem", ou seja, o sujeito entrevistado que, conhecido ou não, compõe a sua imagem - corpo e voz - ao dar um depoimento numa situação que está separada da sua vida cotidiana num ritual com suas regras próprias.

O cinema brasileiro contemporâneo, ao lidar com a experiência social, se confronta com uma esfera pública marcada pela hegemonia exacerbada da televisão como veículo construtor de identidades sociais e regulador das vozes políticas. Como resposta, e não apenas em função disto, os cineastas desenvolveram um contradiscurso de som e imagem voltado para a construção de uma fala que se distancia dos clichês que pautam o discurso da indústria cultural na sua administração do imaginário. Neste gesto, os filmes se mobilizam para produzir um "efeito-de-conhecimento" por diferença, quando um discurso ou um estilo atesta sua potência de revelação pela sua oposição à convenção sedimentada.

No cinema de Coutinho, a cena produzida pelo efeito-câmera procura as falas mais longas que favorecem o aquecimento da personagem que apura a sua auto-mise-en-scène (Comolli 2008), trazendo essa amálgama do programado e do espontâneo, sempre ambíguos em função da mistura de autenticidade e de construção retórica. As pessoas são escolhidas porque se espera que tragam uma forma original de narrar e se fazer personagem ao narrar. Aí, o ponto chave é a "agonia" (Agon) do entrevistado, no sentido de desafio, confronto com o aparato do cinema, sua performance na situação. No cinema de Coutinho, esta é marcada por contingências, mas não é simplesmente puro improviso, uma vez que há uma pesquisa anterior e um 
preparo que antecedem o momento da filmagem. Entrevistas prévias, conduzidas por seus assistentes, auxiliam o cineasta em suas escolhas motivadas pela procura de algo mais ou menos revelador na atuação do sujeito em seu embate com a "opinião pública" representada pela câmera. O toque de Coutinho é ensejar uma performance que ressalte o que cada um tem de singular, e não o que representa na escala social e no contexto da cultura ${ }^{4}$. Tal movimento afirmativo se faz de "narradores de si mesmos" empenhados nessa autoconstrução enquanto personagens que moldam um estilo.

Diante da cena da entrevista, me interessa aqui desenvolver uma reflexão sobre o cinema de Coutinho inserida no debate sobre o enlace entre cinema, teatro e vida na produção do documentário no Brasil. Minha escolha recai sobre Jogo de cena porque este filme toca no nervo dessa tensão que não é nova, mas ganha feição própria na cultura atual em que o documentário confessa o seu reencontro com lado performativo das ações justo quando parece abraçar o real, evidenciando o papel decisivo das tecnologias de imagem e som na intensificação da teatralidade.

\section{Teatralidades}

Gostaria, em primeiro lugar, de fazer uma breve anotação sobre algumas noções citadas, para especificar em que acepção estão aqui assumidas, dentre as várias existentes. Minha referência é Josette Féral que examina os termos "teatralidade", "performance" e "teatro" em Théorie et pratique du théâtre: Au-delà des limites (2011, 79-138).

Féral define teatralidade como uma condição que transcende o teatro, manifestando-se em distintas situações da vida social e do cotidiano, mesmo as que não têm nada a ver com práticas sociais que implicam em protocolos em certo grau de ritualização. O fundamental, para ela, é que a teatralidade é algo que pode se instaurar pela dinâmica do olhar que destaca um campo visível em que as ações, mesmo não sendo intencionadas como performances, tornam-se uma cena graças ao investimento do observador que cria uma ruptura entre o mundo prático, extensivo em seu espaço-tempo, e os movimentos que o olhar põe em foco, concentrando-se em sua dinâmica própria. Esta definição se ajusta ao exemplo, entre outros, que se refere à teatralidade da situação em que, sentados ao ar livre na varanda de um café observamos o movimento da rua como uma cena que nos interessa como manifestação de um estilo, desfile de tipos e atitudes diante de nossos olhos de observadores não implicados no que acontece lá fora. Os cineastas exploram com frequência tais situações criadoras de um ponto de vista especial. É célebre o filme A janela indiscreta, de Hitchcock, no qual Jeff (James Stewart) faz de seu apartamento um lugar privilegiado a partir do qual observa

\footnotetext{
${ }^{4}$ Sobre este aspecto, ver Lins (2002).
} 
as cenas nos apartamentos vizinhos, como um voyeur que a crítica tomou como metáfora do espectador de cinema, mas é necessário acentuar a referência ao espectador de teatro diante da cena, dado que sua janela é um camarote do qual ele não sai (a não ser no momento final em que o vizinho suspeito o ameaça e invade o seu apartamento). Além disso, seu lugar de observação está separado das cenas dos vizinhos pelo "fosso", não aqui um lugar de orquestra, mas do jardim que separa os prédios 5 .

Féral nos lembra que a teatralidade pode, inversamente, ser instituída por um performer que investe o espaço a seu redor daquilo que sua ação, feita para ostentar seu próprio processo, se impõe como uma cena para o olhar dos espectadores que estão na sua órbita, estejam estes numa sala de espetáculos, numa galeria ou no espaço aberto das ruas. Outro fator que gera a teatralidade é o próprio espaço (uma arquitetura, um cenário vazio), dada a promessa de ação teatral que traz em potencial pela sua descontinuidade em relação ao espaço contíguo. Jean-Pierre Sarrazac (2000, 53-71) acentua que tal promessa advém do espaço cênico antes mesmo que comece qualquer performance.

O teatro, em sentido mais específico, seria uma das manifestações da teatralidade, esta que se estabelece a partir de uma ação intencional de atores que se movem em, ou criam um espaço cênico para gerar uma dualidade explícita que o espectador deve perceber entre o real-aqui-agora e o mundo a que a cena remete (ficção), dentro do princípio de que o ator está nesses dois mundos ao mesmo tempo, ou seja, diante da plateia e no espaço-tempo diegético instaurado pela representação. $O$ espectador aceita tal dualidade porque faz parte de sua percepção do espetáculo teatral.

Ao contrário, a arte da performance, em sentido estrito, estaria no plano da presença, não sendo representação que remeteria a um mundo diegético ausente. Como já observei, o performer projeta sua intervenção no espaço imediato e institui o olhar (e a interação) de uma plateia que se defronta com seu poder de criação do gesto que, no limite, se instala de modo a não obedecer à lei da reversibilidade da ação no teatro dramático - neste, o tempo é outro e se pode voltar à estaca zero, repor um estágio anterior sem que sejam irreparáveis as consequências. $\mathrm{Na}$ arte da performance mais canônica, é típica a instabilidade e o risco que inclui a dor efetiva, como no caso de Marina Abramovich. O seu núcleo é o corpo aqui-agora, o que não exclui outras vertentes da arte da performance aptas a consolidar um esquema multimídia que inclui imagens projetadas e outros aparatos que são segmentos fundamentais no espetáculo porque interagem com quem atua ao vivo, implicando outros processos e outros efeitos.

No documentário, o efeito-câmera (olhar e enquadramento que separa um campo visível) é uma instância de teatralidade que

\footnotetext{
${ }^{5}$ Sobre Hitchcock, ver Xavier (2003).
} 
acentua o gesto performativo dos que estão sob o olhar da câmera, como acontece com os entrevistados, cientes de que o registro terá dimensão pública. O essencial aí é explorar a questão dos desdobramentos do sujeito atuante-falante como personagem, na vivência desse jogo ambíguo que o senso comum poderia tomar como uma oposição entre momentos puros de verdade e momentos de mentira, entre sinceridade e fingimento. Neste caso, estaria buscando uma cristalina transparência, em verdade, fora do alcance na situação de filmagem que é já fruto de enquadramento, de um olhar que não é apenas pautado por uma geometria, mas por um fluxo de energia entre câmera e sujeito que se põe como um desafio a quem é observado de perto. O falar de si só convence se a performance conseguir um efeito de autenticidade, não como ilusão de não encenação, mas como autenticidade produzida na encenação.

Tal senso comum formulado em termos da oposição entre verdade e mentira não impede formulações inteligentes, como a que encontramos na fala de Alessandra, personagem de Edifício Master (2001) que joga com estes termos de modo a nos dar um exemplo de intuição da teatralidade e dessa produção de "autenticidade na encenação". Com bom humor, ela comenta a sua condição de "mentirosa verdadeira", depois de contar sua história "sem infância" em que engravidou aos 14 anos e teve uma filha que ela passou a criar sozinha assumindo a condição de "garota de programa". No final da entrevista, respondendo a uma indagação de Coutinho, reconhece que mente muito, mas que também fala a verdade e que suas mentiras de maior empenho definem um regime especial de enunciação marcado pela condição do sujeito falante "acreditar" no que diz, o que torna sua performance convincente, com efeito legitimador até mesmo sobre si.

Esta ênfase na ideia do sujeito da fala acreditar no que diz corresponde ao movimento de assumir uma personagem para quem o conteúdo da sua narração é a verdade, pois - como nos lembra a teoria literária - a narração convincente, encantadora, exige um narrador que assuma o papel de um enunciador para quem tudo o que narra está na esfera do acontecido, como é notório nas instâncias comuns de memória seletiva ou nos mais canônicos exemplos de narrações codificadas em gêneros, como um conto de fadas, um filme de horror ou uma ficção científica.

Em Jogo de cena (2007), a teatralidade da situação ganha conotação específica pela escolha do espaço de um teatro, com sua arquitetura típica. Em tal espaço, a câmera permanece fixa, não explora a mobilidade própria ao olhar do cinema (a menos dos planos em que vemos os entrevistados subirem uma escada e adentrarem o palco). Todas as conversas com o cineasta se dão na mesma posição e, na sucessão das falas, a montagem alterna entrevistas com pessoas comuns que seguem a regra usual, ou seja, o falar de si, e entrevistas envolvendo atrizes (bem conhecidas ou desconhecidas) cuja regra é 
interpretar uma fala transcrita, o registro do depoimento de outra pessoa que, por sua vez, pode ter ou não entrado em cena ao longo do filme. Instala-se um jogo de espelhos nessas falas em que se diz "eu" em chaves diversas, de modo que, neste laboratório onde performances de distintas naturezas são montadas conforme distintos critérios, a questão da representação se põe como motivo central de reflexão. De forma mais explícita, se evidencia a incerteza quanto ao estatuto de certas narrações, fazendo avançar a discussão sobre o que há de indiscernível e o que há de diferente entre o ato performativo como fala de si e ato performativo como prática teatral com o ator seguindo um script.

O filme-ensaio de Coutinho possui dois eixos em sua arquitetura subjacente: (1) a questão da representação no ato da entrevista, considerada a teatralidade e a performatividade aí presentes; (2) o coro de vozes femininas que institui um universo intersubjetivo de experiência e de imaginário cujos motivos se entrelaçam e compõem um mosaico revelador.

\section{Jogo de cena}

O filme se abre com a exibição de um anúncio em jornal convocando mulheres "que tem histórias para contar" para vir fazer um teste tendo em vista a sua participação em um documentário. Na sala de espetáculos com a plateia vazia, há apenas uma cadeira no palco, em frente a uma câmera, à cadeira do diretor e à equipe de filmagem. Um senso a priori de encenação serve de moldura para as entrevistas.

O enquadramento usado no filme se opõe ao do espectador de teatro. A câmera está dentro, no fundo do palco, e seu olhar está dirigido para o entrevistado que dá as suas costas para a plateia vazia, ao fundo e iluminada. Com frequência, o seu rosto ocupa toda a tela de modo a destacar os jogos de fisionomia que compõem a sua performance.

A primeira entrevistada é Sheila que sobe a escada, na penumbra, até chegar ao palco onde Coutinho e sua equipe a esperam. Em sua fala, é enfática no comentário à sua precoce "pretensão", como ela mesma diz, de ser atriz desde muito jovem, algo que reconhece como fora de propósito dada a sua falta de formação. O que viabilizou o improvável foi o fato de ter sido aceita no grupo de teatro "Nós do morro" de uma favela do Rio de Janeiro, onde foi educada para o teatro e para a vida. No percurso, veio a trabalhar na peça Gota d'água de Chico Buarque e Paulo Pontes, uma adaptação de Medeia, a tragédia clássica de Eurípedes. Ela fez, na encenação do grupo, o papel da protagonista que, em versão moderna, atualiza o paradigma da vingança radical, a violência trágica da mulher traída.

É irônico o teor desta entrevista. De imediato, ela nos traz uma narradora-atriz que, embora fale de si e nos convença de que a histó- 
ria é sua, já aponta o problema da competência da atriz e seus requisitos, algo que vai ecoar em outras narrações de personagens que também explicitam a sua condição de atriz de teatro, de modo a alterar a nossa recepção de seus comportamentos performativos, embora estejam lá convocadas pelo anúncio de jornal e falando supostamente de si.

No final de sua breve fala, Sheila interpreta uma cena da peça, a pedido de Coutinho. Em seguida, passamos para uma longa sequência, a da entrevista de uma moça cujo nome é Gisele, sequência de que participa uma atriz conhecida, Andréa Beltrão, cuja função é repetir a narração de Gisele num espelhamento que revela de imediato a sua regra. A montagem alternada enlaça a participação da atriz com a da personagem (Gisele) que ela interpreta. É inevitável aqui o desafio da comparação quando a vemos compor a fala de uma personagem em carne e osso, a cuja performance ela assistiu no vídeo, situação distinta da representação de uma personagem instituída por um texto dramático a quem a atriz, depois da leitura, doa seu corpo e sua voz.

A tônica da fala de Gisele é a vida afetiva em que se destacam duas relações nas quais teve filhos com companheiros de quem se separou após o nascimento. O dado traumático de seu relato é a perda de seu filho Vitor quando recém nascido, acontecimento que ela insere num imaginário espírita para explicar tanto o nascimento (em que ela atendeu a um chamado de reencarnação) quanto a morte dele (nova mensagem recebida traz as imagens que fazem tal morte ganhar sentido e se pacificar). A experiência da dor é superada pela fé na continuidade da vida em outro lugar.

$\mathrm{Na}$ alternância das falas de Gisele e Andréa - que se revezam na continuidade e no entrelaçamento dos relatos, o filme não somente joga com a diferença entre as duas performances como também introduz, na interpretação de Andréa, uma pausa para a reflexão que permite a conversa entre ela e Coutinho sobre o método e sobre o estilo de interpretação. A atriz, falando do seu trabalho e de suas dificuldades, deixa claro que o pressuposto de uma interpretação realista é fundamental na condução do processo em todo o filme, marcando a presença do método de Stanislavski para engendrar um processo de identificação com a personagem.

Deste modo, as atrizes se valem de sua própria experiência, ativando a sua memória afetiva para reviver emoções que correspondam à exigência da cena num registro realista. Coutinho lhes pediu uma interpretação que, embora não fosse imitação restrita, tivesse o cuidado de não sugerir qualquer descompasso com os sentimentos e valores expressos nas entrevistas. Isto se evidencia na conversa com Andréa quando ela comenta as lágrimas involuntárias e seu efeito na sua atuação; queria evitar o melodrama, mas não se conteve em decorrência da identificação emocional com a personagem. Ela comenta 
que Gisele foi mais serena na sua performance ao narrar a perda do filho porque o espiritismo a ajudou a suportar a morte de um ser tão próximo, algo impossível para ela própria, Andréa, que sente a dor da morte das pessoas a quem ama como irremediável.

A questão do melodrama é um espectro que ronda quase todas as performances, dados os assuntos dominantes nas narrações (romance familiar e relações amorosas), e é interessante notar que a serenidade de Gisele não está distante do que acontece em outras entrevistas. Dentro da gradação de tons na narração de experiências dramáticas, se há um ou outro excesso, não há o cultivo de uma autovitimização diante da dor ou a exibição enfática de lágrimas, mesmo quando estas efetivamente ocorrem, exceto no caso de Sarita, comentado adiante, que é a figura dos excessos melodramáticos no filme, superlativa no humor e no choro.

A atriz Marília Pêra, quando interpreta Sarita, dentro do mesmo esquema de alternância, opta pelo gesto mais contido e uma fala mais pausada. No entanto, mesmo na diferença de tom, acompanha as flutuações da postura de sua personagem diante das figuras do romance familiar que ela traz à cena.

A narração de Sarita é pautada pela admiração pelo pai (algo recorrente nos depoimentos) e pela mãe. De um casamento morno e efêmero, resultou a filha que é figura central em seu depoimento. É enorme o seu amor por ela, e todo o drama de Sarita vem do conflito doloroso e, até o momento, definitivo que teve com ela quando a visitou nos Estados Unidos, onde mora há algum tempo. Seu relato é pontuado por choro, meneios de cabeça, gestos enfáticos. Marília Pêra, no momento de sua conversa com Coutinho na pausa para reflexão, não critica Sarita, e deixa claro que, embora também ela tenha sentido, ao interpretar, a força da memória afetiva e a sua própria condição de mãe como parte do jogo, se conteve. A seu ver, quem vive uma emoção em situações da vida mesma tenta evitar o choro diante dos outros, por pudor. O ator melodramático, não. Quer exibi-lo. E ela acrescenta ironicamente que, se o cineasta tivesse pedido para ela chorar, tinha consigo o recurso do cristal japonês (ela o mostra) que faz as atrizes chorar nas cenas de tele-ficção. A lágrima é bem-vinda na telenovela.

Uma nova entrevistada, Aleta, como que segue o preceito de Marília Pêra e se contém com vigor em certos momentos, embora se vislumbre a sua forte emoção ao observar que tinha sonhos de liberdade (ida para o estrangeiro) dissolvidos pela gravidez precoce e o nascimento da filha, fruto de uma relação logo terminada E tal contenção se repete quando enfrenta outro momento de emoção lacrimosa, porém controlada, quando relata o seu momento de reconciliação com a vida quando reconheceu que, apesar das renúncias geradas pela maternidade, aprendeu muito com a filha (a quem deve a sua maturação). 
Fernanda Torres, a atriz que interpreta Aleta em outra alternância dos relatos, explicita o forte sentimento de estar sendo testada quando, na sua atuação, há um momento de desconforto em que se sente vulnerável diante do olhar de Coutinho e não consegue prosseguir. $\mathrm{O}$ momento de travo é exposto sem cortes, mostrando a hesitação e o seu movimento de "sair" da personagem Aleta para comentar o seu problema. O curioso é que neste momento ela diz a Coutinho "parece que eu estou mentindo para você", nos lembrando a ideia de que é preciso que o ator acredite na sua fala como "verdadeira" para ser convincente. Já comentei esse fato a propósito da fala de Alessandra, a personagem de Edifício Master, que intuiu a nova versão do "paradoxo do comediante", agora às voltas com a questão da autenticidade na encenação. Este senso do "acreditar" ou estar convicto, no caso das atrizes, tem a ver com a procura da imitação convincente num jogo interessado em marcar as diferenças entre o caminho (não o efeito) da atriz ao construir um papel a partir de um texto e o caminho (não o efeito) de alguém que compõe uma performance para dar conta de um fragmento de autobiografia. Justapostas de forma nítida, a performance das atrizes famosas que interpretam as narrações de outras personagens, e a performance das mulheres que atenderam ao chamado do jornal para contar suas próprias histórias são duas formas de teatralidade que evidenciam esta diferença em seu modo de produção. E o dado crucial é que as duas formas produzem um efeito similar de autenticidade que resulta do movimento de identificação das atrizes com as personagens, este movimento cujos problemas discutem com o cineasta nas pausas para reflexão inseridas no jogo.

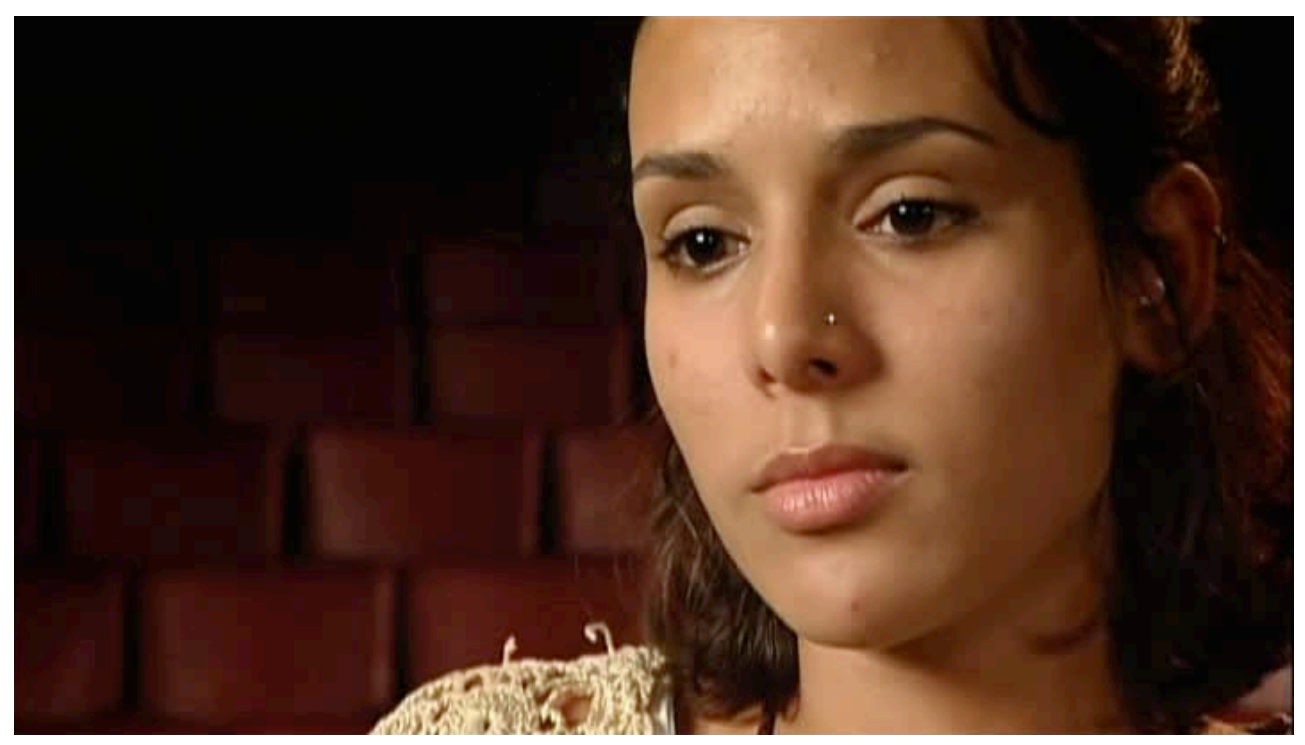




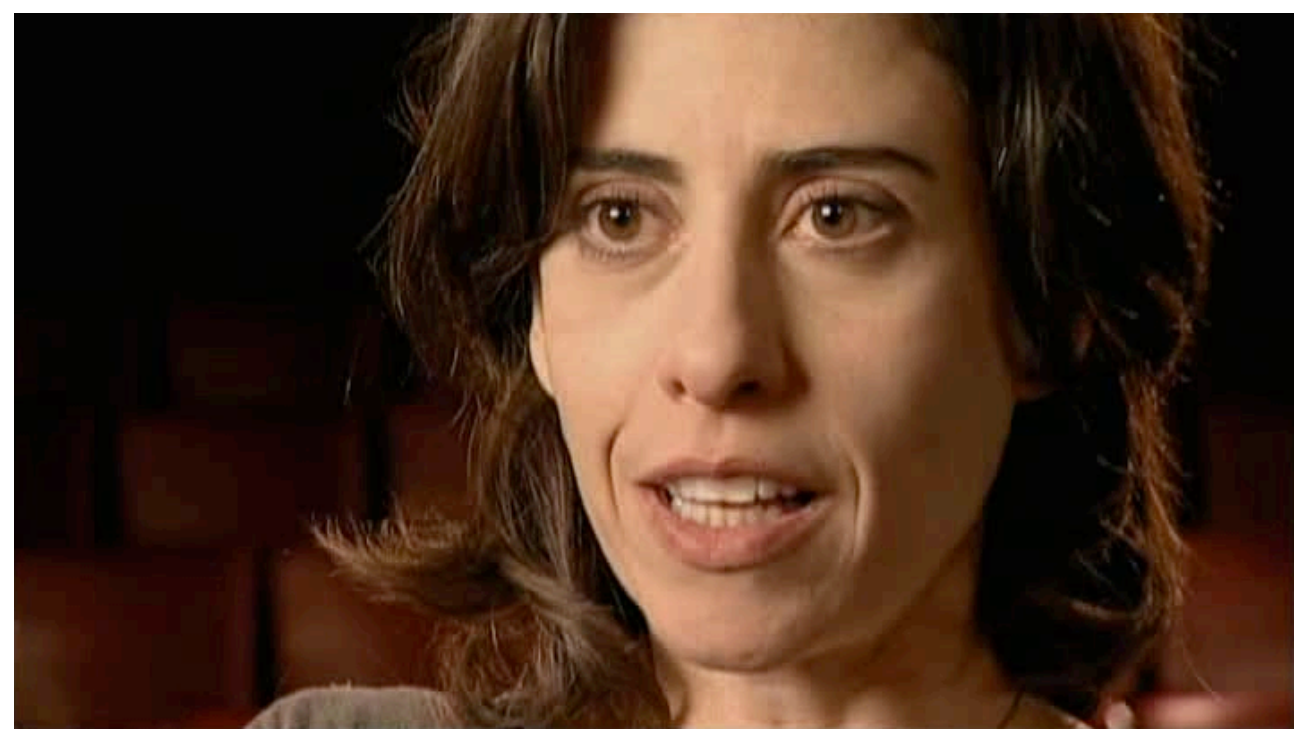

Imagens 1 e 2: Aleta Gomes Vieira e Fernanda Torres em Jogo de Cena (Eduardo Coutinho, 2007) | (c) Matizar e VideoFilmes

Terminada a alternância entre as falas de Aleta e de Fernanda Torres, esta volta à questão proposta por Andréa Beltrão, comentando a dificuldade de interpretar uma figura real cuja fala ela assimilou e cuja performance observou numa gravação em vídeo. O movimento vivo de corpo e voz da moça, ali visível, estabelece um parâmetro que "esfrega na sua cara" a impossibilidade de chegar ao ponto desejado na criação da personagem. Ela vê Aleta como o gabarito rigoroso de sua performance de atriz, e vê seu desafio como bem distinto daquele enfrentado por Aleta quando esta constrói a sua própria imagem ao falar de si na entrevista, visto que é seu próprio modo de se tornar presente e se compor como personagem. Fernanda destaca, por exemplo, a diferença de ritmo na exposição do que é desdobramento memorialístico na composição da fala do passado (que é de Aleta e não dela), e na expressão de emoções associadas a tal passado.

Variantes da montagem do filme articulam de outras formas a inserção das entrevistas nesta dinâmica de identidade e diferença, evidenciando o quanto a performance das personagens que falam de si em chave autobiográfica e as que resultam do trabalho de outras atrizes desconhecidas que interpretam a partir de um script produzem o mesmo efeito de verossimilhança, autenticidade e convencimento. Isto é demonstrado pelo filme em várias ocasiões.

Primeiro, quando uma personagem, após narrar com humor e charme o que pensamos ser sua história, temperada de comentários sobre o seu estilo de incorporar as contingências da vida, termina com uma alteração de fisionomia e de tom dizendo para a câmera "foi isso que ela disse", revelando que acaba de interpretar a narração de outra moça que não aparece no filme.

Em segundo lugar, quando uma fala, dando conta de uma história de vida e seus sentimentos de decepção e dor, se repete 
literalmente nas performances de duas mulheres - em dois momentos ligeiramente afastados na sucessão das entrevistas - sem que seja possível discernir de quem é a história. Ambas são convincentes e dotadas do mesmo "efeito de autenticidade" de quem narra a sua experiência. Neste caso, estamos presos à moldura de cada cena e não temos dados vindos de outra esfera para distinguir quem fala de si e quem é uma atriz que interpreta um texto, faz teatro em sentido estrito.

Em terceiro lugar, há novas dúvidas quando Andréa Beltrão e Fernanda Torres cumprem nova função no jogo de cena ao serem protagonistas de outra variante. Elas aparecem em outros momentos do filme para contar experiências supostamente vividas por ela, enfim um relato autobiográfico. Diante da performance delas, não há como discernir se estão narrando um episódio que viveram mesmo ou uma situação de vida narrada num texto ou na fala de outras personagens que não aparecem na tela, pois não temos os dados extracena relativos à vida delas e não podemos refazer o caminho que as levaram a tais performances; nos falta o seu método de produção.

Limitados ao que vemos diretamente nas cenas das entrevistas, sem a ajuda da montagem, não eliminamos as incertezas quanto a quem está falando do seu próprio passado ou narrando, em primeira pessoa, a experiência vivida por outrem. Daí a opção de Coutinho de fazer da montagem - e também do fato de que se trata de atrizes bem conhecidas - o fator de explicitação da regra do jogo quando o revezamento das falas envolve Andréa, Marília e Fernanda. Não seria possível, pelo menos para um espectador brasileiro, não notar que interpretavam narrações de outras moças. Faz parte de seu papel no jogo o interromper a sua interpretação para comentar os problemas enfrentados.

Colocada a esta questão da equivalência no efeito de autenticidade alcançado por distintas formas de performance, o referencial trazido por Josette Féral tem como função aqui definir os pontos extremos de um modelo, com a distinção entre a teatralidade própria à performance no sentido mais amplo, que é presença e autoconstrução de si como personagem pública, e a teatralidade própria à representação da atriz de teatro em que há a construção explícita de uma alteridade mediada por um texto. Tal esquema ajuda a pensar o problema, desde que exercitado, e relativizado, no corpo a corpo com as situações examinadas que evidenciam como os distintos modos de atuação envolvem os mesmos processos de desdobrar-se, "ser outro", de criação de imagem, embora não da mesma forma.

Jogo de cena conta com a referida equivalência dos efeitos de autenticidade na encenação. Esta é um foco de incertezas que a montagem do filme toma como ponto de partida para explorar as variantes do jogo, visando conduzir o debate sobre os efeitos que, em verdade, já estavam implicados no trabalho de Coutinho, notadamen- 
te a partir do momento em que a entrevista passou a ser a forma dramática exclusiva de seus documentários. Estes se movimentam no terreno do cinema moderno e se inserem num contexto dramático e narrativo que potencializa as ambiguidades aqui discutidas e renova as formas de criação de personagens dentro de uma combinação peculiar de cálculo e acidente que cabe ao entrevistador explorar. Coutinho é mestre na procura de narradores que, em cena, interagem com ele e trabalham a sua imaginação para se identificar com a construção, aqui e agora, de um percurso a que são capazes de dar vida de modo convincente.

\section{Enunciação intersubjetiva e formação do imaginário}

Feita esta discussão, lembremos que a indagação do filme vai além da questão do teatro como representação, ou da performance e sua noção de presença. A esta complexa equação, que o cineasta trabalha sem buscar uma tese ou soluções apressadas, vem se articular a exposição de uma condição da mulher que vem a primeiro plano ao longo das entrevistas. Neste outro eixo, a reflexão que se impõe é dirigida ao conteúdo das narrações. Estas não são desencontradas em seus temas, pelo contrário. Expressivas, elas se referem, quase sempre, a uma forma de viver e reagir de modo afirmativo a perdas, frustrações, conflitos na esfera familiar, ou se referem a uma forma de viver uma condição identitária num contexto social gerador de entraves.

Cada personagem narra experiências em que há a construção de um imaginário que oferece uma resposta à dor causada por uma separação ou pela morte de filhos ou de pais. Isto permite a lida com universos de afeto exacerbado ou possíveis traumas que precisam ser trabalhados em construções simbólicas que os tornem suportáveis, pela via religiosa e seus sistemas, ou pela fé em visões nas quais, como num sonho, aparece a figura foco de conflitos ou remorsos para liberar a personagem de sua angústia.

Neste sentido, o caso de Sarita é singular. No final, ela volta à cadeira do entrevistado, ela que já expusera antes seu conflito doloroso com a filha. Retorna porque achou a sua performance muito "trágica" e quer dissolver a impressão causada sem, no entanto, abandonar o seu sentimentalismo. Ela quer cantar. Fala do seu pai e da canção de ninar, foco de memórias de infância, e escolhe a cantiga popular "Se essa rua fosse minha". A voz e o choro compõem a atmosfera de saudade da inocência, ressalvado que um dos temas da cantiga é o "bosque chamado solidão" que se insinua no seu ideal romântico. Este recuo ao imaginário infantil dá o tom ao último gesto de uma personagem do filme, a mesma cuja recusa do trágico é ambivalente, mas garante uma irônica simetria em relação à primeira performance do filme, a da moça que evocou o gesto trágico de $\mathrm{Me}$ deia. O final vem completar um percurso que parecia como que levado ao acaso, mas que se fez uma articulação temática deste coro 
de vozes femininas que compõem um discurso intersubjetivo que nos dá, no conjunto, uma demonstração das formulações de Mikhail Bakhtin $^{6}$ sobre o caráter dialógico de todo enunciado, sobre a presença do Outro na fala do sujeito, neste caso narrações que dão conta de uma experiência de solidão, correlata à constante ausência da figura masculina quando surgem demandas efetivas.

Neste capítulo final, temos o único momento em que emerge uma voz over a se sobrepor à cena: Marília Pêra faz uma segunda voz discreta ao fundo da canção até o fim desta, e encaminha o corte para o plano final de Jogo de cena. Com a câmera colocada no ponto de vista da última fileira da plateia do teatro, temos a imagem do palco vazio, onde, solitárias, restam as duas cadeiras onde sentaram o cineasta e todas as mulheres entrevistadas. Aqui, o cenário vazio não é propriamente uma promessa de teatro como diria Sarrazac em sua definição de teatralidade, mas um espaço impregnado pela memória do jogo de cena e seus fantasmas. A particular feição desse final com a cantiga é um desfecho sugestivo do movimento reflexivo deste ensaio, pois nos remete à questão do canto e da narração a partir da observação de Wolfgang Kayser (1970) em sua teoria da narrativa, quando acentua o quanto, na performance da narração que encanta e convence, há que se construir um ponto de vista de quem acredita inteiramente no que conta, pois narrar é assumir uma identidade ou, se quisermos, uma personagem afinada com o imaginário que a própria narração constrói, tal como deve fazê-lo um contador de histórias infantis empenhado em imprimir em seus ouvintes a convicção da concretude do ocorrido. Em outros termos, empenhado em produzir o encanto que propicia uma vivência do imaginário cujo papel é formador, uma espécie de matriz retrabalhada ao longo da vida em distintos encontros entre experiência e imaginação, teatro e a vida.

Ao finalizar, vale aqui reiterar a nuance fundamental trabalhada por Coutinho no cotejo entre as manifestações da teatralidade presentes em Jogo de cena, lembrando que, embora possam ser indiscerníveis em seu efeito, tais manifestações são distintas no seu processo de produção e composição. Este é um processo que entendemos melhor ao considerar o percurso que vai do sentido geral e abrangente de teatralidade às feições particulares das suas manifestações na cultura, em especial estas que o efeito-câmera catalisa como narrações que se equivalem em seu "efeito de autenticidade". O cineasta contou com isto ao armar o jogo, escolher as mulheres entrevistadas, instruir as atrizes. Não foi sua proposta montar um laboratório de performances cujas equações tenham validade universal, uma vez que a interpretação das atrizes poderia ter outro critério e outras variáveis poderiam alterar o horizonte do jogo. Da mesma forma, não foi meu objetivo formular uma teoria geral das relações entre as distintas modalidades de performance, e muito menos dar

\footnotetext{
${ }^{6}$ Ver Bakhtin (2009) e Brait (2009).
} 
conta da complexa gama de atravessamentos de fronteira próprios às experiências teatrais contemporâneas em diferentes espaços.

Dentro do recorte escolhido, Jogo de cena é um notável ensaio que problematiza o campo da representação e esclarece alguns pontos, convidando, por outro lado, a aprofundar a reflexão sobre os enlaces de oralidade, gestualidade, narração e teatralidade, aqui mediadas pelo cinema num processo de contornos indefinidos.

\section{BIBLIOGRAFIA}

Adorno, Theodor. 1962. "El ensayo como forma." In Notas de literatura, Theodor Adorno, 11-36. Barcelona: Ediciones Ariel.

Bakhtin, Mikhail. 2009. Marxismo e Filosofia da Linguagem. São Paulo: Hucitec.

Brait, Beth, org. 2009. Bakhtin: dialogismo e polifonia. São Paulo: Ed. Contexto.

Comolli, Jean-Louis. 2008. Ver e poder: A inocência perdida: cinema, televisão, ficção, documentário. Belo Horizonte: Editora UFMG.

Deleuze, Gilles. 1985. Cinema: a imagem-movimento. São Paulo: Brasiliense.

Féral, Josette. 2011. Théorie et pratique du théâtre: Au-delà des limites. Montpellier: L'Entretemps.

Kayser, Wolfgang. 1970. "Qui raconte le roman?” Poétique 4, dezembro.

Liandrat-Guigues, Suzanne e Murielle Gagnebin, dir. 2004. L'essai et le cinema. Seyssel: Éditions Champ Vallon.

Lins, Consuelo. 2002. "Coutinho encontra as fissuras do Edifício Master." Sinopse 9, agosto: 30-32.

Richter, Hans. 1940. "Der Filmessay, eine neue form de Dokumentarfilms." Nationalzeitung, 24 de abril, cit. in Fihman Guy. 2004. "L'essai cinématographique et ses transformations expérimentales." In Critique du théâtre: de l'utopie au désenchantement, Jean-Pierre Sarrazac, 42-43. Belfort: Éditions Circé.

Sarrazac, Jean-Pierre. 2000. "L'invention de la théâtralité." In Critique du théâtre: de l'utopie au désenchantement, Jean-Pierre Sarrazac, 53-71. Belfort: Éditions Circé.

Starobinski, Jean. 1985. "Peut-on définir l'Essai ?" In Cahiers pour un temps, Jean Starobinski, 185-96. Paris: Centre Georges Pompidou. 
48 | ISMAIL XAVIER

Xavier, Ismail. 2003. O olhar e a cena: Melodrama, Hollywood, Cinema Novo, Nelson Rodrigues. São Paulo: Cosac Naify. 